\title{
Maternal MTHFR polymorphisms and risk of spontaneous abortion
}

\author{
María del Rosario Rodríguez-Guillén, MCs, ${ }^{(1)}$ Luisa Torres-Sánchez, Dr SP, ${ }^{(1)}$ Jia Chen, PhD, ${ }^{(2)}$ \\ Marcia Galván-Portillo, Dr SP,(1) Julia Blanco-Muñoz, MCs, (1) Miriam Aracely Anaya, PhD, (3) Irma Silva-Zolezzi, PhD, (4) \\ María A Hernández-Valero, PhD, ${ }^{(5)}$ Lizbeth López-Carrillo, $\mathrm{Dr}$ PH. ${ }^{(1)}$
}

\section{Rodríguez-Guillén MR, Torres-Sánchez L, Chen J, Galván-Portillo M, Blanco-Muñoz J,Anaya MA, Silva-Zolezzi I, Hernández-Valero MA, López-Carrillo L. Maternal MTHFR polymorphisms and risk of spontaneous abortion.} Salud Publica Mex 2009;5 I:19-25.

\begin{abstract}
Objective. To asses the association between intake of folate and $B$ vitamins and the incidence of spontaneous abortion (SA) according to the maternal methylenetetrahydrofolate reductase (MTHFR) polymorphisms (677 C>T and 1298 $\mathrm{A}>\mathrm{C}$ ). Material and Methods. We conducted a nested case-control study within a perinatal cohort of women recruited in the state of Morelos, Mexico. Twenty-three women with SA were compared to 74 women whose pregnancy survived beyond week 20th. Intake of folate and B vitamins respectively, was estimated using a validated food frequency questionnaire. Maternal MTHFR polymorphisms were determined by PCR-RFLP and serum homocysteine levels by HPLC. Results. Carriers of MTHFR 677TT and I298AC genotypes respectively showed an increased risk of SA (OR 677TT vs. $\mathrm{CC} / \mathrm{CT}=5.0 ; 95 \% \mathrm{Cl}: \mathrm{I} .2,20.9$ and $O R$ I $298 \mathrm{AC}$ vs. $\mathrm{AA}=5.5$; $95 \%$ Cl: I.I, 26.6). Conclusions. Our results support the role of MTHFR polymorphisms as a risk factor for SA, regardless of dietary intake of $B$ vitamins.
\end{abstract}

Key words:MTHFR; 677 C >T and I298A $>$ C polymorphisms; spontaneous abortion; Mexico
Rodríguez-Guillén MR, Torres-Sánchez L, Chen J, Galván-Portillo M, Blanco-Muñoz J,Anaya MA,

Silva-Zolezzi I, Hernández-Valero MA, López-Carrillo L. Polimorfismos maternos MTHFR y riesgo de aborto espontáneo.

Salud Publica Mex 2009;5I:19-25.

\section{Resumen}

Objetivo. Evaluar la asociación entre aborto espontáneo (AE) y el consumo dietético de vitaminas $B$ en mujeres mexicanas portadoras de los polimorfismos de la metilentetrahidrofolato reductasa (MTHFR) (677 C >T y $1298 \mathrm{~A}>\mathrm{C}$ ). Material y métodos. Mediante un diseño de casos y controles anidados en una cohorte, se comparó la ingesta dietética materna de vitaminas B y folato, los polimorfismos maternos de la MTHFR y la concentración sérica de homocisteina de 23 casos de $A E$ ( $\leq 20$ semanas) y 74 controles (mujeres con embarazos $>20$ semanas). Resultados. Las portadoras de los genotipos MTHFR 677TT y 1298AC presentaron un incremento significativo en el riesgo de $A E$ (RM 677TT vs. $\mathrm{CC} / \mathrm{CT}=5.0 ;$; $95 \%$ : I.2, 20.9 RM I $298 \mathrm{AC}$ vs. $\mathrm{AA}=5.5 ;$; $\mathrm{C} 95 \%$ : I.I, 26.6), respectivamente. Conclusiones. Nuestros resultados apoyan el papel de la mutación de la MTHFR como posible factor de riesgo para el $A E$, independientemente del consumo de vitaminas $B$.

Palabras claves: MTHFR; aborto espontáneo; polimorfismos 677 C>T y 1298 A>C; México

(I) National Institute of Public Health. Morelos, México.

(2) Departments of Community and Preventive Medicine, Pediatrics, and Oncological Sciences, Mount Sinai School of Medicine, New York. New York, USA.

(3) Universidad Autónoma del Estado de Querétaro. Escuela de Nutrición, Facultad de Ciencias Naturales. México.

(4) Mexican Institute of Genomic Medicine. Mexico City, Mexico.

(5) Department of Health Disparities Research, Center for Research on Minority Health, The University of Texas M.D. Anderson Cancer Center. Houston, Texas, USA.

Received on: March 5, 2008 • Accepted on: August 13,2008

Address reprint resquests to: Dra. Lizbeth López-Carrillo. National Institute of Public Health.Av. Universidad 655, col. Santa. María Ahuacatitlán. 62508, Cuernavaca, Morelos, México. E-mail: lizbeth@insp.mx 
Cpontaneous abortion (SA) is defined as the loss of fetal product before 20 weeks of gestation. ${ }^{1}$ Lifestyle, diet, and, more recently, maternal genetic characteristics have been proposed as determinants of SA. Specifically, maternal and paternal smoking ${ }^{2-4}$ and maternal alcohol and coffee consumption during pregnancy have been associated with a higher risk of SA. ${ }^{5-7}$ In addition, low folate levels in maternal serum ${ }^{8}$ and suboptimal folate metabolism, indicated by the presence of hyperhomocysteinemia, have also been associated with recurrent abortions. ${ }^{9}$ The relationship of SA with intakes of other $B$ vitamins that are involved in folate metabolism, i.e. B2, B6 and B12, has not been well established. ${ }^{10-12}$

Methylenetetrahydrofolate reductase (MTHFR), a key folate-metabolizing gene, is located on chromosome 1 . Several non-synonymous single nucleotide polymorphisms (SNPs) are present in the coding region of the gene including positions 677 and $1298 .{ }^{13}$ The most studied SNP is the $677 \mathrm{C}>\mathrm{T}$ substitution that results in an amino acid change from alanine to valine at codon $225 .^{14}$ The MTHFR 1298A $>$ C polymorphism results in a substitution of glutamate with alanine. ${ }^{15,16}$

MTHFR enzyme activity is reduced by $35 \%$ among the $677 \mathrm{CT}$ carriers and by 50\% to 70\% among 677TT carriers. ${ }^{14}$ The function of polymorphism 1298A>C has not been consistently demonstrated; however carriers of the heterozygous genotypes (677CT/1298AC) show MTHFR activity similar to that in MTHFR677TT carriers. ${ }^{15}$ The reduction in MTHFR activity increases homocysteine levels and in turn reduces the availability of the DNA methyl groups. ${ }^{17,18}$

The associations reported to date between maternal MTHFR $677 \mathrm{C}>\mathrm{T}$ and $1298 \mathrm{~A}>\mathrm{C}$ polymorphisms and risk of SA have been inconsistent. ${ }^{19-29}$ Some authors reported as much as a three-fold increase in SA risk among women carriers of the 677TT genotype compared to women with the 677CC or 677CT genotypes, ${ }^{23-26}$ while other authors found no association at all. ${ }^{19,20,22,27} \mathrm{An}$ increased risk for SA was also observed in fetal carriers of the MTHFR 677T allele. ${ }^{21,28,29}$

The prevalence of the MTHFR 677TT genotype is higher among Mexicans (36-48\%) compared to Europeans $(7.8-18 \%) ;{ }^{13}$ in contrast, a much lower frequency of the MTHFR 1298C allele has been observed in the Mexican population ( 0 to $2.4 \%$ vs. 7.5 to $11.5 \%$ ) than in Europeans. ${ }^{30,31}$

The objective of this study was to evaluate the risk of SA according to maternal MTHFR polymorphisms (677 C>T and $1298 \mathrm{~A}>\mathrm{C}$ ) and other lifestyle risk factors in a cohort of Mexican women residing in the state of Morelos in Mexico.

\section{Material and Methods}

We conducted a nested case-control study within an ongoing perinatal cohort of women that began in January 2001; the cohort had been formed to evaluate the effect of environmental exposure to organochlorine on infant neurodevelopment. Study participants were recruited from four municipalities in the state of Morelos, Mexico, during premarital counseling mandated by Mexican law. To be eligible for the study, women had to be nonlactating and without a history of chronic diseases. A detailed description of the methodology and cohort follow-up is reported elsewhere. ${ }^{32}$

Women were contacted every six weeks by telephone or household visit and asked to report a ten-day delay in their menstrual period to confirm a pregnancy status with a pregnancy test, or clinically document the presence of a SA.

Twenty-three women with SA (pregnancy that ended spontaneously before 20 weeks) with a median gestational age of 10 weeks ( $\min =6$ and $\max =17$ ), were identified among a group of 456 women who became pregnant before July 2004, and 74 women whose pregnancies lasted beyond 20 gestational weeks, with a median gestational age of $37.2(\min =21$ and $\max =42)$, were randomly selected as controls.

Home interviews were conducted on both women and their husbands / partners to elicit sociodemographic information (e.g., partners' / husband's occupation), reproductive history, and dietary habits before pregnancy, alcohol consumption prior to conception and tobacco use. During the baseline evaluation, each woman's weight and height were measured to calculate her body mass index (BMI), and a blood sample $(7 \mathrm{ml})$ was obtained to determine her MTHFR genotypes and homocysteine serum levels.

This study was approved by the Institutional Review Board of the National Institute of Public Health of Mexico. Informed consent was obtained from study participants and their husbands.

\section{Genotyping of the MTHFR $677 \mathrm{C}>\mathrm{T}$ and I 298 A>C polymorphisms}

Genomic DNA was extracted using a QIAamp DNA Blood Mini Kit (QUIAGEN, Valencia, CA). DNA amplification and genotyping of MTHFR $677 \mathrm{C}>\mathrm{T}$ and 1298 $\mathrm{A}>\mathrm{C}$ were performed by polymerase chain reaction (PCR-RFLP) according to the protocol suggested by Chen et al. ${ }^{33}$ and Weisberg et al. ${ }^{16}$ For quality control purposes, for each batch of PCR-amplified samples, one 
sample containing a known genotype and one negative control were analyzed. In addition, duplicate analyses of $10 \%$ of the samples, randomly selected, were performed by a technician who was blinded to the first set of results and reached Kappa correlation coefficients of 1 and 0.954 for the MTHFR $677 \mathrm{C}>\mathrm{T}$ and MTHFR $\mathrm{A}>\mathrm{C}$ 1298 genotype determinations respectively.

\section{Dietary intake of folate and B vitamins}

Dietary intake of folate and vitamins $B_{2}, B_{6}$, and $B_{12}$ was estimated by means of a validated semi-quantitative food frequency questionnaire (FFQ) containing 95 different items. ${ }^{34}$ For each food item, there was a defined portion, and women were asked to choose from 10 consumption frequency options, which ranged from never to six times per day. The consumption of 28 individual nutrients (including total caloric intake) was calculated using the Food Intake Analysis Software 3.0 (FIAS, Texas University, USA). A detailed description of the methods used to calculate nutritional intake has been published elsewhere. ${ }^{35}$

On the FFQ the following foods were considered sources of vitamins $B_{2}, B_{6^{\prime}}$ and folate: liver, beans, lentils, green beans, peas, tomatoes, spinach, lettuce, potatoes, cauliflower, broccoli, chili peppers, beets, carrots, avocados, oranges, papayas, mangos, strawberries, bananas, tangerines, melons, plums, pears, pineapples, apples, peaches, grapes, lamb, tuna, pork and steak; while the dietary intake of vitamin $B_{12}$ was based in the consumption of liver, sardines, tuna, pork, lamb, steak, fish, chocolate, beer, and red and white wines.

\section{Determination of serum homocysteine levels}

Total serum homocysteine levels were determined in duplicated analysis using a high performance liquid chromatography (HPLC) method previously described by Gilfix et al. ${ }^{36}$ Fluorescent intensities were measured with excitation and emission wavelengths set at 385 and $515 \mathrm{~nm}$, respectively. Quality control (Liquicheck Homocysteine Control- Bilevel, Biorad Inc) showed 98.4\% $\pm 2.7 \%$ and $99.1 \pm 1.2 \%$, recovery for the low and the high level, respectively. CV between duplicate sample analysis was $5.2 \pm 2.8 \%$.

\section{Statistical analysis}

Selected maternal and paternal characteristics were compared between cases and controls. Based on the median values observed in the control group the following categories were created for: maternal age ( $\leq$ 21vs. $>21$ years), education ( $\leq 9$ vs. $>9$ years), body mass index $(\leq 22.4$ vs. $>22.4)$, and paternal age $(\leq 24$ vs. $>24$ years).

Paternal occupation was categorized as "risky" or "non-risky" according to the occupation types that have been assessed with relation to $S A:{ }^{37}$ poultry farmer, bricklayer, painter, maintenance worker, farmer, potter, flower-grower, pesticide applicator, and blacksmith. Due to the skewed dietary distributions, nonparametric tests were used to compare, between cases and controls, the folate and $B$ vitamins intakes respectively. We estimated the Hardy-Weinberg equilibrium test among controls to evaluate the observed and expected frequencies of the genotypes of interest. ${ }^{38}$ The risk of spontaneous abortion (SA) in relation to dietary consumptions of folate and $B$ vitamins as well as the presence of maternal methylenetetrahydrofolate reductase (MTHFR) polymorphisms (677 C>T and $1298 \mathrm{~A}>\mathrm{C}$ ) was estimated using odds ratios (ORs) and their respective $95 \%$ confidence intervals $(\mathrm{CIs})$ with a recessive hereditary model, and further stratify by early and late abortion ( $\leq 10$ and $>10$ weeks). STATA (College Station, Texas, USA) statistical software version 9.0 was used to conduct all of the analyses.

\section{Results}

Compared with homemakers, women with paid employment had an almost three-fold borderline significant increased risk of SA $(O R=2.7 ; 95 \%$ CI: 1.0, 7.1). Smoking (before pregnancy) as well as paternal occupation resulted in increased risks of SA respectively, however this was not significant. In contrast, maternal younger age and higher education showed non-significant protection of SA (table I).

As described in table II, non-significant higher dietary intakes of folate and B vitamins were observed among controls compared to cases, except for vitamin $\mathrm{B}_{6}$ intake, which resulted in the border of significance ( 2.1 vs. $1.8 \mathrm{mg} / \mathrm{d} ; p=0.09$ ). Cases in contrast to controls, showed a non-significant higher median of homocysteine serum levels, as well as the MTHFR 677TT genotype (43.5\% vs. 25.7\%). No carriers of the MTHFR 1298CC genotype were present in this study population. The median values of homocysteine remained different (with no statistical significance) between cases and controls, after further stratification by the alleles of interest $(677 \mathrm{C}$ : Cases $=9.6$ vs. Controls $=10.3 \mu \mathrm{mol} / \mathrm{L} ; 677 \mathrm{~T}$ : Cases $=11.0$ vs. Controls $=10.4 \mu \mathrm{mol} / \mathrm{L} ; p>0.05 .1298$ A Cases $=10.4 \mathrm{vs}$. Controls $=10.5 \mu \mathrm{mol} / \mathrm{L} ; 1298 \mathrm{C}$ : Cases $=9.8$ vs. Controls $=$ $8.8 \mu \mathrm{mol} / \mathrm{L} ; p>0.05$. ) (data not included in the table). Among the controls, neither of the genotype distributions showed any deviance from the Hardy-Weinberg equilibrium. 
Table I

Association betWeen SELECTEd MATERnAl AND PATERnAL CHARACTERISTICS AND BETWEEN CASES AND CONTROLS. Morelos, MeXico, 200 I-2004

\begin{tabular}{|c|c|c|c|c|}
\hline Characteristics & $\begin{array}{c}\text { Cases } \\
(n=23)\end{array}$ & $\begin{array}{l}\text { Controls } \\
(n=74)\end{array}$ & $O R$ & $95 \% \mathrm{Cl}$ \\
\hline \multicolumn{5}{|l|}{ Maternal } \\
\hline \multicolumn{5}{|l|}{ Age (years) } \\
\hline$>21$ & 12 & 33 & 1.0 & \\
\hline$\leq 21$ & 11 & 41 & 0.7 & $0.3-1.9$ \\
\hline \multicolumn{5}{|l|}{ Education (years) } \\
\hline$\leq 9$ & II & 35 & 1.0 & \\
\hline$>9$ & 12 & 39 & 0.9 & $0.4-2.5$ \\
\hline \multicolumn{5}{|l|}{ Previous pregnancies } \\
\hline None & 19 & 62 & 1.0 & \\
\hline $\mathrm{I}-2$ & 4 & 12 & 1.1 & $0.3-3.8$ \\
\hline \multicolumn{5}{|l|}{ Body mass index } \\
\hline$>22.4$ & II & 37 & 1.0 & \\
\hline$\leq 22.4$ & 12 & 37 & 1.1 & $0.4-2.8$ \\
\hline \multicolumn{5}{|l|}{ Smoked before pregnancy } \\
\hline No & II & 41 & 1.0 & \\
\hline Yes & 12 & 33 & 1.4 & $0.5-3.5$ \\
\hline \multicolumn{5}{|l|}{ Occupation } \\
\hline Household activities & 9 & 47 & 1.0 & \\
\hline Paid employment & 14 & 27 & 2.7 & $1.0-7.1$ \\
\hline
\end{tabular}

Paternal

\begin{tabular}{|c|c|c|c|c|}
\hline \multicolumn{5}{|l|}{ Age (years) } \\
\hline$\leq 24$ & II & 35 & 1.0 & \\
\hline$>24$ & 12 & 39 & 1.0 & $0.4-2.5$ \\
\hline \multicolumn{5}{|l|}{ Occupation* } \\
\hline Non-risky & 14 & 61 & 1.0 & \\
\hline Risky & 5 & $\mathrm{II}$ & 2.0 & $0.6-6.6$ \\
\hline \multicolumn{5}{|c|}{ Alcohol intake (cups/week)* } \\
\hline$\leq \mathrm{I}$ & 8 & 25 & 1.0 & \\
\hline$>1$ & 9 & 26 & 1.1 & $0.4-3.2$ \\
\hline \multicolumn{5}{|l|}{ Smoking status* } \\
\hline No & 7 & 34 & 1.0 & \\
\hline Yes & 12 & 34 & 1.7 & $0.6-4.9$ \\
\hline
\end{tabular}

* Due to missing values, numbers for these variables do not equal the total of cases and controls

‡ Poultry farmer, bricklayer, painter, maintenance worker, farmer, potter, flower-grower, pesticide applicator or blacksmith

Under a recessive inheritance model, a significantly increased adjusted risk of $\mathrm{SA}(\mathrm{OR}=5.0 ; 95 \% \mathrm{CI}: 1.2,20.9)$ was detected among carriers of the MTHFR 677TT compared to carries of MTHFR CC+CT, that remained after stratifying by abortion type (early or late). Also, the MTHFR 1298 AC genotype increased the risk of SA
$(\mathrm{OR}=5.5 ; 95 \%$ CI:1.1, 26.6) when compared with the wild type. This result remained significant among late abortions and it was not evaluated among early abortions due to the small sample size.

\section{Discussion}

This study detected an increased risk of SA among female carriers of the MTHFR 677TT and MTHFR1298 AC genotypes, independent of other factors previously associated with increased SA risk (paternal tobacco use and maternal occupation). These results support the findings of recent studies ${ }^{23-26}$ that have shown an effect of homozygosity for MTHFR $677 \mathrm{C}>\mathrm{T}$ on early-late recurrent abortions, but should be interpreted with caution due to the small sample size of this study.

The median levels of all $\mathrm{B}$ vitamins examined, i.e. folate, vitamins $\mathrm{B}_{2^{\prime}} \mathrm{B}_{6^{\prime}}$ and $\mathrm{B}_{12^{\prime}}$ were lower in SA cases compared to the controls, although the difference did not reach significance. It is important to point out that multivitamin supplementation is low in the Mexican population, ${ }^{39}$ as was the case in this small study population. Thus, these findings need to be replicated in larger studies to fully evaluate the protective role of these vitamins on SA risk.

Similar to the findings in other Mexican populations, ${ }^{30,31,40-42}$ a high percentage of our study population, both cases and controls, were carriers of the MTHFR 677T allele (58.7\% and $52.0 \%$, respectively), and a low frequency of the $1298 \mathrm{C}$ allele $(11.4 \%$ and $9.5 \%$, respectively) was observed. Given our small sample size and the low frequency of the MTHFR 1298 CC in the Mexican population $(2.3 \% \text {; } 95 \% \mathrm{CI}: 0.9-4.6)^{30}$ no carriers of this genotype were present in the participating women. No information about genotypes of interest in the father or even more in the fetuses was available for this study to evaluate their effects on the risk of SA.

A previous similar study conducted by Borja-Aburto et al. ${ }^{43}$ in Mexico City that included 668 women $16-40$ years of age, reported an incidence of SA of $6 \%$, which is equal to our estimation and lower than the 12-15\% reported in other, foreign populations. ${ }^{44}$ To interpret the estimation of SA occurrence, some methodological considerations should be mentioned: in this study women were mainly primigravidae $(\sim 80 \%)$, an incidence of SA among primigravidae and women with history of live births is low $(5 \%)^{44}$ thus differences in SA throughout studies may partially be attributed to differences in the reproductive history of participants. Also, it is possible that some underestimation of the actual SA incidence exists due to the fact that the majority of pregnancy losses are early as a result of karyotypic abnormalities of conceptus and are difficult to detect without perform- 
Table II

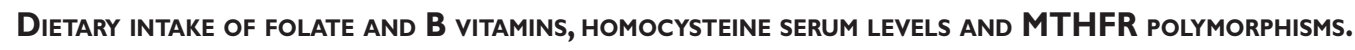

Morelos, MeXico, 200 I-2004

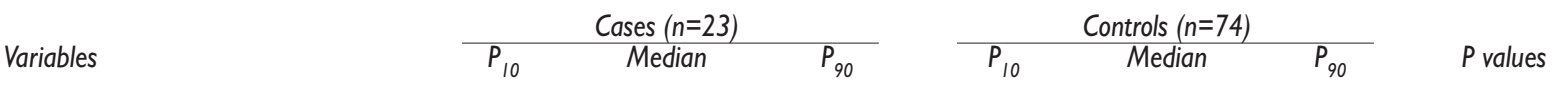

Dietary Intake

\begin{tabular}{lrrrrrrr} 
Folate, $\mu \mathrm{g} / \mathrm{d}$ & 131.7 & 341.4 & 514.2 & 231.6 & 392.9 & 580.8 & $0.18^{*}$ \\
\hline Vitamin $\mathrm{B}_{2}, \mathrm{mg} / \mathrm{d}$ & 1.1 & 2.1 & 2.5 & 1.6 & 2.2 & 3.4 & $0.16^{*}$ \\
\hline Vitamin $\mathrm{B}_{6}, \mathrm{mg} / \mathrm{d}$ & 0.9 & 1.8 & 2.7 & 1.2 & 2.1 & 3.3 & $0.09^{*}$ \\
\hline Vitamin $\mathrm{B}_{12}, \mathrm{mg} / \mathrm{d}$ & 1.9 & 3.2 & 6.3 & 1.8 & 3.8 & 8.2 & $0.52^{*}$
\end{tabular}

Homocysteine serum level $(\mu \mathrm{mol} / \mathrm{L})$

5.7

10.2

14.8

6.8

9

13.4

$0.53^{*}$

Polymorphisms

(\%)

(\%)

MTHFR $677 C>T^{\S}$

\begin{tabular}{cccc} 
CC & 26.1 & 21.6 & \\
\hline CT & 30.4 & 52.7 & $0.15^{\ddagger}$ \\
\hline TT & 43.5 & 25.7 & \\
MTHFR I298A>C S.\# & & & \\
AA & 77.3 & 81.1 & $0.69^{\ddagger}$ \\
\hline AC & 22.7 & 18.9 &
\end{tabular}

* Based on Mann-Whitney tests

\# Based on $\chi^{2}$ tests

$\S$ Hardy-Weinberg equilibrium test among controls for MTHFR 677C $>$ T and MTHFR I298 A $>C>0.05$

\# I case had missing values for MTHFR I298A>C

$P_{10-90}:$ Percentile 10 and 90

Table III

MTHFR 677C>T AND I 298A >C POLYMORPHISMS AND RISK OF SPONTANEOUS ABORTIONS in a Mexican perinatal cohort. Morelos, Mexico, 200 I-2004

\begin{tabular}{|c|c|c|c|c|c|c|c|c|c|c|}
\hline \multirow[b]{2}{*}{ Polymorphisms } & \multicolumn{2}{|c|}{ All } & \multicolumn{4}{|c|}{ Early Abortions ( $\leq 10$ weeks) } & \multicolumn{4}{|c|}{ Late Abortions ( $>10$ weeks) } \\
\hline & $O R^{\prime}$ & $95 \% \mathrm{Cl}$ & Cases & Controls & $O R^{2}$ & $95 \% \mathrm{Cl}$ & Cases & Controls & $O R^{3}$ & $95 \% \mathrm{Cl}$ \\
\hline \multicolumn{11}{|c|}{ MTHFR $677 C>T^{*}$} \\
\hline $\mathrm{CC}+\mathrm{CT}$ & 1.0 & -- & 5 & 55 & 1.0 & -- & 8 & 55 & 1.0 & -- \\
\hline TT & 5.0 & $1.2,20.9$ & 4 & 19 & 5.2 & $0.75 ; 35.6$ & 6 & 19 & 5.8 & $0.82 ; 4 I . I$ \\
\hline
\end{tabular}

MTHFR I298A>C†.\$

\begin{tabular}{ccccccccccccc} 
AA & 1.0 & - & 8 & 60 & - & - & 9 & 60 & 1.0 & - \\
\hline AC & 5.5 & $1.1,26.6$ & 1 & 14 & - & - & 4 & 14 & 9.7 & $1.4 ; 68.8$
\end{tabular}

* Risk adjusted for maternal occupation, MTHFR $298 \mathrm{~A}>\mathrm{C}$, folate intake and caloric intake and husband's smoking status

‡ Risk adjusted for maternal occupation, MTHFR 677C > T, folate intake and caloric intake and husband's smoking status

$\S$ I case had missing values for the MTHFR I298A>C 
ing a longitudinal assessment of beta human chorionic gonadotrophin $(\beta-\mathrm{hCG}){ }^{45}$ that was the case of this study and might have reduced the power to detect significant associations. Balancing these limitations is the strength of our study design, a nested case-control study, where dietary information and sera were obtained at recruitment and allow showing the temporality of the studied variables.

Maternal paid employment was associated with risk of SA in our study population. However, interpretation of this result is limited since we did not collect detailed work-related information such as the number of hours worked, type of exposures, etc. Our findings regarding paternal tobacco use are consistent with the study conducted by Venners et al, ${ }^{3}$ which reported an almost twofold increase of SA among women whose husbands smoked more than 20 cigarettes per day, however the limited sample size precluded the ability to find statistically significant results that should be replicated in future larger cohorts.

The mechanism by which the MTHFR polymorphisms increase the risk of SA is not known. Previously, authors have hypothesized that the increased risk may be due to an increase in homocysteine levels, ${ }^{18,46}$ which is consistent with the higher levels of homocysteine that we detected in our cases compared to the controls. Hyperhomocysteinemia reduces the methyl availability; ${ }^{47}$ methylation is an important epigenetic characteristic that plays an important role in DNA repair and the stability of the genome. Both MTHFR677 C>T and the MTHFR1298 A>C polymorphisms have been associated with decreased levels of DNA methylation. ${ }^{17}$ Experimental evidence also suggests that aberrant DNA methylation may contribute to the under-development observed in fetal cow clones. ${ }^{48}$

Prevention of SA should consider metabolic dietary differences among the genetically susceptible population. Future larger cohort studies are needed to fully evaluate the interaction between the genetic characteristics and the periconception intakes of folate and other related B vitamins in high risk populations.

Funding: This study was supported by the Consejo Nacional de Ciencia y Tecnología de México/CONACyT (41708, 31034-M, 13915). Support for María del Rosario Rodríguez Guillén was provided by the Mount Sinai School of Medicine International Training and Research in Environmental and Occupational Health Program (D43TW00640).

\section{Acknowledgements}

We want to thank Ms. Stephanie Deming, Department of Scientific Publications, The University of Texas M. D. Anderson Cancer Center for her valuable editorial comments.

The authors declare that they have not conflicts of interest.

\section{References}

I. Speroff L, Glass RH, Kase NG. Clinical Gynecologic Endocrinology and Infertility. 6th ed. Baltimore: Lippincott Williams \&Wilkins, 1999: 1043. 2. Chatenoud L, Parazzini F, Di Cintio E, Zanconato G, Benzi G, Bortolus R, et al. Paternal and maternal smoking habits before conception and during the first trimester: relation to spontaneous abortion. Ann Epidemiol 1998; 8: 520-526.

3.Venners SA, Wang X, Chen C, Wang L, Chen D, Guang W, et al. Paternal smoking and pregnancy loss: a prospective study using a biomarker of pregnancy.Am J Epidemiol 2004; I59: 993-100I.

4.Windham GC, Swan SH, Fenster L. Parental cigarette smoking and the risk of spontaneous abortion. Am J Epidemiol 1992; I35: I394- | 403.

5. Cnattingius S, Signorello LB,Anneren G, Clausson B, Ekbom A, Ljunger E, et al. Caffeine intake and the risk of first- trimester spontaneous abortion. N Engl J Med 2000; 343: I839- I845.

6. Di Cintio E, Parazzini F, Chatenoud L, Surace M, Benzi G, Zanconato $\mathrm{G}$, et al. Dietary factors and risk of spontaneous abortion. Eur J Obstet Gynecol Reprod Biol 2001; 95: I32-I36.

7. Rasch V. Cigarette, alcohol, and caffeine consumption: risk factors for spontaneous abortion. Acta Obstet Gynecol Scand 2003; 82: I82-I88. 8. George L, Mills JL, Johansson AL, Nordmark A, Olander B, Granath F, et al. Plasma folate levels and risk of spontaneous abortion. JAMA 2002; 288: 1867-1873.

9. Nelen WL, Blom HJ, Steegers EA, den Heijer M, Eskes TK. Hyperhomocysteinemia and recurrent early pregnancy loss: a metaanalysis. Fertil Steril 2000; 74: II96-II99.

10. Gindler J, Li Z, Berry RJ, Zheng J, Correa A, Sun X, et al. Folic acid supplements during pregnancy and risk of miscarriage. Lancet 200 I; 358 : 796-800.

II. Ronnenberg AG, Goldman MB, Chen D,Aitken IW,Willett WC, Selhub J, et al. Preconception folate and vitamin B(6) status and clinical spontaneous abortion in Chinese women. Obstet Gynecol 2002; 100: I07-II3.

12. Rumbold A, Middleton P, Crowther CA.Vitamin supplementation for preventing miscarriage. Cochrane Database Syst Rev 2005; 2: CD004073. 13. Botto LD, Yang Q. 5, 10 Methylenetetrahydrofolate reductase gene variants and congenital anomalies: a huge review.Am J Epidemiol 2000; |5I:862-877.

14. Frosst P, Blom HJ, Milos R, Goyette P, Sheppard CA, Matthews RG, et al. A candidate genetic risk factor for vascular disease: a common mutation in methylenetetrahydrofolate reductase. Nat Genet 1995; I0: III-I I3. I5. Van der Put NM, Gabreels F, Stevens EM, Smeitink JA, Trijbels FJ, Eskes $\mathrm{TK}$, et al.A second common mutation in the methylenetetrahydrofolate reductase gene: an additional risk factor for neural- tube defects? Am J Hum Genet 1998; 62: 1044-1051. 
16. Weisberg I,Tran P, Christensen B, Sibani S, Rozen R.A second genetic polymorphism in methylenetetrahydrofolate reductase (MTHFR) associated with decreased enzyme activity. Mol Genet Metab 1998; 64: 169-172.

17. Castro R, Rivera I, Ravasco P, Camilo ME, Jakobs C, Blom HJ, et al. 5, I0-methylenetetrahydrofolate reductase (MTHFR) 677C_T and I298 A_C mutations are associated with DNA hypomethylation.J Med Genet 2004; 41: 454-458.

18. Rosen R. Genetic predisposition to hypermocysteinemia: deficiency of methylene tetrahydrofolate reductasa (MTHFR).Thromb Haemost 1997; 78: 523-526.

19. Foka Z], Lambropoulos AF, Saravelos H, Karas GB, Karavida A, Agorastos T, et al. FactorV Leiden and prothrombin G20210A mutations, but not methylenetetrahydrofolate reductase $\mathrm{C} 677 \mathrm{~T}$, are associated with recurrent miscarriages. Hum Reprod 2000; 15: 458-462.

20. Holmes ZR, Regan L, Chilcott I, Cohen H. The C677T MTHFR gene mutation is not predictive of risk for recurrent fetal loss. $\mathrm{Br} J$ Haematol 1999; 105: 98-101.

21. Isotalo PA, Wells GA, Donelli JG. Neonatal and fetal methylenetetrahy drofolate reductase genetic polymorphisms: an examination of C677T and A I298C mutations. Am J Hum Genet 2000; 67: 986-990.

22. Kutteh WH, Park VM, Deitcher SR. Hypercoagulable state mutation analysis in white patients with early first-trimester recurrent pregnancy loss. Fertil Steril 1999; 7I: 1048-1053.

23. Nelen WL, Steegers EA, Eskes TK, Blom JH. Genetic risk factor for unexplained recurrent early pregnancy loss. Research letter Lancet 1997; 350:861.

24. Unfried G, Griesmacher A, Weismüller W, Nagele F, Huber CJ, Tempfer CB. The C677T polymorphism of the methylenetetrahydrofolate reductase gene and idiopathic recurrent miscarriage. Obstet Gynecol 2002; 99:614-619.

25. Xu L, Liu XM, Zhang HY, Zhao J, Qi QW, Chang YF. Relationship between three thrombophilic gene mutations and unexplained recurrent early spontaneous abortion. Zhonghua Fu Chan Ke Za Zhi 2007;42:180-183. 26. Mtiraoui N, Zammiti W, Ghazouani L, Braham NJ, Saidi S, Finan RR, et al. Methylenetetrahydrofolate reductase C677T and A 298C polymorphism and changes in homocysteine concentrations in women with idiopathic recurrent pregnancy losses. Reproduction 2006; |3 |:395-40I.

27. Wrambsy ML, Sten-Linder M, Bremme K. Primary habitual abortions are associated with high frequency of factor $\mathrm{V}$ Leiden mutation. Fertil Steril 2000; 74: 987-991.

28. Zetterberg H, Regland B, Palmer M, Ricksten A, Palmquist L, Rymo $\mathrm{L}$, et al. Increased frequency of combined methylenetetrahydrofolate reductase $\mathrm{C} 677 \mathrm{~T}$ and $\mathrm{AI} 298 \mathrm{C}$ mutated alleles in spontaneously aborted embryos. Eur J Hum Genet 2002; 10: I 13-1 I8.

29. Zetterberg H, Zafiropoulos A, Spandidos DA, Rymo L, Blennov K. Gene-gene interaction between fetal MTHFR 677C $>\mathrm{T}$ and transcobalamin $776 \mathrm{C}>\mathrm{G}$ polymorphisms in human spontaneous abortion. Hum Reprod 2003; 18: 1948-1950.

30. Gueant-Rodriguez RM, Gueant JL, Debard R, Thirion S, Hong LX, Bronowicki JP, et al. Prevalence of methylenetetrahydrofolate reductase 677T and I298C alleles and folate status: a comparative study in Mexican, West African, and European populations. Am J Clin Nutr 2006; 83: 70I-707. 31. Torres-Sanchez L, Chen J, Diaz-Sanchez Y, Palomeque C, Bottiglieri T, Lopez-Cervantes M, et al. Dietary and genetic determinants of homocysteine levels among Mexican women of reproductive age. Eur J Clin Nutr 2006; 60:691-697.
32. Torres-Sánchez L, Rothenberg SJ, Schnaas L, Cebrian ME, Osorio E, Hernandez M, et al. In Utero p,p'-DDE Exposure and Infant Neurodevelopment:A Perinatal Cohort in Mexico. Environ Health Perspec 2007; 15:435-439.

33. Chen J, Giovannucci E, Kelsey K, Rimm EB, Stampfer MJ, Colditz GA, et al.A methylenetetrahydrofolate reductase polymorphism and the risk of colorectal cancer. Cancer Res 1996; 56: 4862-4864.

34. Hernández-Avila M, Romieu I, Parra S, Hernández-Avila J, Madrigal H, Willet W.Validity and reproducibility of a food frequency questionnaire to assess dietary intake of women living in Mexico City. Salud Publica Mex 1998; 39: 133-140.

35. López-Carrillo L, López-Cervantes M,Ward MH, Bravo-Alvarado J, Ramírez-Espitia A. . Nutrient intake and gastric cancer in México. Int J Cancer 1999; 83:60I-605.

36. Gilfix BM, Blank DW, Rosenblatt DS. Novel reductant for determination of total plasma homocysteine. Clin Chem 1997; 43: 687-688.

37. Savitz DA, Sonnenfeld NL, Olshan AF. Review of epidemiologic studies of paternal occupational exposure and spontaneous abortion. Am J Ind Med 1994; 25:36I-383.

38. Griffiths A, Miller J, Suzuki D, Lewontin R, GelbartW. Genética. 3ra ed. Madrid:Mc Graw Hill, 2002: 722-723.

39. Blanco-Muñoz J, Lacasaña-Navarro M,Torres-Sánchez LE, Borja-Aburto V, García-García AM, López-López L. Socioeconomic factors and the risk of anencephaly in a mexican population: a case-control study. Public Health Reports 2005; 120: 39-45

40. Gonzalez-Herrera L, Garcia-Escalante G, Castillo-Zapata I, CantoHerrera J, Ceballos-Quintal J, Pinto-Escalante D, et al. Frequency of the thermolabile variant C677T in the MTHFR gene and lack of association with neural tube defects in the state of Yucatan, México. Clin Genet 2002; 62: 394-398.

4I. Martinez-de Villarreal LE, Delgado-Enciso I,Valdez-Leal R, OrtizLopez R, Rojas-Martinez A, Limon-Benavides C, et al. Folate levels and $\mathrm{N}(5), \mathrm{N}(\mathrm{I0})$-methylenetetrahydrofolate reductase genotype (MTHFR) in mothers of offspring with neural tube defects: a case-control study. Arch Med Res 2001; 32: 277-282

42. Mutchinick O, López AM, Luna L,Waxman J, Babinsky E, RYVEMCE Collaborative Group. High prevalence of the thermolabile methylenete trahydrofolate reductase variant in México: a country with a very high prevalence of neural tube defects. Mol Genet Metabol 1999; 68: 46I-467. 43. Borja-Aburto VH, Hertz-Picciotto I, Rojas-López M, Farias P, Ríos $\mathrm{C}$, Blanco J. Blood lead levels measured prospectively and risk of spontaneous abortion. Am J Epidemiol 1999; I50: 590-597. 44. Regan L, Rai R. Epidemiology and the medical causes of miscarriage. Baillieres Best Pract Res Clin Obstet Gynaecol 2000; 14: 839-854. 45. Wilcox AJ,Weinberg CR, O'Connor JF, Baird DD, Schlatterer JP, Canfield RE, et al. Incidence of early loss of pregnancy. N Engl J Med 1988;319:189-194.

46. Ueland PM, Hustad S, Schneede J, Refsum H,Vollset SE. Biological and clinical implications of the MTHFR C677T polymorphism. Trends Pharmacol Sci 200I; 4: 195-20I.

47. Jiang Y, Sun T, Xiong J, Cao J, Li G, Wang S. Hyperhomocysteinemiamediated DNA hypomethylation and its potential epigenetic role in rats. Acta Biochim Biophys Sin (Shanghai) 2007;39:657-667.

48. Chen T, Jiang Y, Zhang YL, Liu JH, Hou Y, Schatten H, et al. DNA hypomethylation of individual sequences in aborted cloned bovine fetuses. Front Biosci 2005; 10: 3002-3008. 